far more than 50 species have been recognised that have not previously been recorded from Great Britain, including at least 13 new to science. The particular aim of the collecting undertaken was the study of the fauna occurring in association with the relict arctic-alpine flora peculiar to elevations above $2,500 \mathrm{ft}$. In one group alone, consisting of the sawflies, four species new to science, and 13 new to Great Britain were obtained, with a total of 18 species peculiar to the region specially investigated.

\section{Botany at the Natural History Museum}

Mr. J. D. SNowden has presented to the Department of Botany his herbarium of 2,300 plants. During his period of service as agricultural officer in Uganda, Mr. Snowden was an enthusiastic botanical collector with great opportunities of which he made full use. His collections rank, both in number and quality, among the best from the Protectorate, and include many plants discovered by himself. The specimens presented to the Museum formed his own personal set. Some of the plants were collected in the littleknown Acholi Hills in the south of the Sudan, but the great majority came from Uganda, particularly from Mount Elgon, the flora of which-like that of the other great African mountains-is of exceptional interest. As an agricultural officer, Mr. Snowden knew just what was required, and his material is accompanied by adequate notes. He paid special attention to grasses, a group in which his name is commemorated by the genus Snowdenia.

SIR J. L. Hanham, who accompanied Mr. J. M. Wordie's recent arctic expedition, made a collection of plants from West Greenland (500 numbers) and Baffin Land (200 numbers), together with a few lichens and mosses. Plants in the arctic are well known to be shy flowerers, and this collection contains exceptionally good specimens; they are unusually well dried, whereas so many arctic collections have suffered much from mould and mildew owing to the great humidity of the atmosphere in high latitudes. As a result, this collection is a valuable one apart from the fact that it has been made in little-known regions. Mrs. E. M. Day has presented the paintings of larger fungi made by her late husband. They number 1,400. Most of them have been examined by eminent mycologists or have been drawn from specimens named by them. An interesting fern herbarium of about 500 specimens from Trinidad has been presented by Archdeacon A. Hombersly. The herbarium is in very good condition and is of particular value as the donor used his collection as the basis of an account of the ferns of Trinidad which is now being prepared for Press. Mr. E. Heron-Allen has presented a copy of the valuable first edition of the "Thesaurus Evonymi Philiatri de remediis secretis", by Conrad Gesner, 1557. This is a rare book, particularly in the first edition. It makes an interesting addition to the collection of herbals in the Department of Botany.

\section{Die Physik}

THE quarterly journal Die Physik in Regelmässigen Berichten, which is sponsored by the German Society for Technical Physics, has completed its second year. As the full title implies, its contents are mainly surveys of larger or smaller fields of physics, the average length of an article being about 15 pages. The thirteen subjects dealt with range widely, and include hygrometry, acoustics, medical physics, corpuscular radiations and general quantum theory, the balance between the old and the new physics being carefully maintained. It is presumably the intention to give further surveys with the same titles, as the subjects develop, since the title of each article is followed by the numeral I. The reviews appear very thorough, considering the space available, and are all by acknowledged experts in their subjects. Thus F. Henning writes on thermal apparatus, M. Pirani on illuminants and illumination, W. O. Schumann on dielectrics and $\mathrm{G}$. Wentzel on quantum theory and wave mechanics.

A FEATURE of the publication is the method of citing references to investigations mentioned in the surveys. Whenever possible, the volume and page number of the abstract in the Physikalischen Berichte is given, without more detailed reference, a note at the end of every article explaining that this has been done. Additional references are collected together at the end of the survey. An innovation which seems to have little to recommend it is that of numbering the pages of each survey independently, and printing this page number on the top corner of the leaf. A second set of page numbers running serially through the volume is also provided, but is in a less conspicuous position, at the bottom corner of the leaf. The periodical is published by J. A. Barth of Leipzig, and the annual subscription (post free) is 24.60 gold marks.

\section{A New Modified Bunsen Burner}

THE Bunsen burner is one of those simple and ingenious contrivances that could only have emanated from the brain of a practical genius. Unlike some of his successors to-day, Bunsen was never a SchreibtischChemiker; flouting speculative hypotheses, he excelled in practical work of many kinds, and in devising his celebrated burner he created for himself a memorial that may well outlast his fame as an analytical investigator. Generations of chemists and physicists come, use his burner, and go; yet the principle of it stands fast. From time to time a useful modification, for example, the Meker and the Teclu, arises, and the latest, which has recently been marketed by Messrs. Amal Ltd., of Birmingham, appears to belong to this category. In this burner, a very sensitive control of the gas flow is obtained by means of a needle-valve, inserted in the orifice of the jet, which is capable of very fine adjustment by an external screw. Air-regulation is unnecessary, and the flame can be reduced almost to invisibility, by means of the needle-valve, without flashing back. As in the Meker burner, the combustion-head is perforated with many small holes, so that the flame consists of a cluster of perfectly aerated small cones. Attached to the base is an insulated hooked strip of metal for use as a holder should the burner become 
hot. The Amal burner is supplied in several sizes, that for ordinary use measuring $5 \frac{1}{2} \mathrm{in}$. high and one inch across the head, and costing 12s. $6 d$.

\section{Value of Anti-Diphtheritic Serum Treatment}

The autumn issue of the Fight against Disease (22, No. 4), the quarterly journal of the Research Defence Society, contains an article by Sir Leonard Rogers showing the reduction in the suffering and the deaths of children from diphtheria during the last forty years consequent upon the use of anti-diphtheritic serum treatment. He points out that the case mortality, the most scientific test of the value of treatment, from diphtheria in the hospitals of the Metropolitan Asylums Board, has steadily fallen every year from a percentage of 30.4 in 1890-93 before serum was used, to 9.0 in $1905,7 \cdot 4$ in 1910 , and less than 4.0 in 1933, following the treatment of the disease with the serum. More striking still is the fall in mortality for laryngeal cases, from 62 per cent in 1894 to $11 \cdot 7$ in 1910. The value of the serum treatment is even more conclusively shown by its remarkable efficacy in the early stages of the disease, as compared with its comparative failure when given after the fourth day of the disease, when the toxæmia of the disease is fully developed, in accordance with what animal experiments had indicated would be the case. The case mortality per cent when treatment is commenced on the first day of the disease is only $1 \cdot 6$, on the second day it is $7 \cdot 9$, and on the third $17 \cdot 2$. As Sir Charles Martin has pointed out, "If the antitoxin (serum) were a remedy of no value, whether it was administered on the first or on the fifth day of the disease would be immaterial". Clinical evidence is no less conclusive: many doctors still living can testify to the horrors of diphtheria in young children in the pre-serum days. This is now all changed, and the young diphtheria patient if treated early with serum will rarely succumb. Sir Leonard Rogers estimates that had the pre-serum mortality from diphtheria continued since 1911, there would have been 250,000 more deaths from diphtheria than were actually recorded.

\section{Television in the United States}

THE October issue of Electronics contains an illustrated article surveying the principal systems of television which are undergoing development in the United States of America. Of the six systems reviewed, four employ a cathode ray oscillograph type of tube for both transmission and reception; while the other two employ mechanical-optical systems comprising a vibrating mirror or a rotating mirrored disc, in conjunction with a photoelectric cell for transmission and a Kerr cell for reception. All the methods are capable of transmitting scenes photographed on the standard size of cinematograph film; most of them are also suitable for the transmission of studio scenes, while some can be successfully operated on outdoor scenic material. The number of scanning lines into which the picture is dissected for transmission varies from 60 to 400 , while an average value of 240 lines is very popular.
The transmission of such a picture at the standard cinematograph rate of 24 per second requires a communication channel of the order of $1,000 \mathrm{kc} . / \mathrm{sec}$, as compared with the space of 9 or $10 \mathrm{kc} . / \mathrm{sec}$. permitted in modern sound broadcasting. Such a large band-width is considered to be essential for satisfactory picture reproduction, and this technical limitation presents one of the most serious problems to the television worker. It requires transmitting and receiving circuits of great complexity and high cost, and it would appear to limit the available wave. band for broadcast television to the ultra-short region below 10 metres. The article referred to discusses briefly the prospects of the commercial application of television in America, and expresses the opinion that in addition to the technical problems, there are other difficulties of a financial nature involved in the provision of a television programme service throughout the country.

\section{General Šrtefánik}

General Mrlan R. Šttefánik had the distinction of being almost the only Slovak man of science to attain any eminence since the time of Komensky (1592-1670). He studied in Paris, and before the War became secretary of the Observatory at Meudon and went on several French scientific missions. During the War, he was an air force officer in France, Serbia and Italy before becoming Czechoslovak Minister of National Defence in 1918. $\mathrm{He}$ was unfortunately killed when his aeroplane crashed near Bratislava as he was returning home in May 1919. Some account of his work has now been placed on record in a book recently published by Eos, Bratislava. The author, Mr. Ferdinand Písecky, was closely associated with General Stefánik during his missions in Russia and the United States, and the book is a valuable addition to Czechoslovak literature; although it deals primarily with Stefánik's War career and his political activities, occasional reference is made to his scientific work.

\section{Eskimo Studies}

A PRIZE of a gold medal and a thousand crowns has been offered by the Royal Academy of Sciences and Letters of Denmark for a study of Eskimo origins. In the statement of the conditions upon which this prize is offered for competition, it is pointed out that there are two main opposing views on the origins and ethnological affinities of the Eskimo. The older of the two theories to which reference is made derives from the views put forward by the Danish authority, J. H. Rink, in 1871, that the Eskimo were of close affinity to the Indians of North America and had originated in a comparatively restricted centre in the interior of the American continent, from which they had migrated to Alaska and afterwards spread across the northern area as far as Greenland. Later, the place of origin was defined more precisely as in the neighbourhood of Hudson Bay. The alternative theory, which it may be said is that now more generally held, is that tho Eskimo, while showing affinities with the Indians, 